\title{
Difference of calcium levels in Javanese, Madurese, and Chinese preeclamptic women
}

\author{
Nuzulul Azizah Ramdan Wulandari', Ernawati ${ }^{2}$, Muhammad Ilham Aldika Akbar ${ }^{3}$ \\ 'Midwifery Study Program Faculty of Medicine Airlangga University, ${ }^{2}$ Department of Obstetrics and Gynaecology, \\ Dr.Soetomo General Hospital, Universitas Airlangga Hospital/Faculty of Medicine Airlangga University
}

\begin{abstract}
ABSTRAK
Tujuan: Menganalisis perbedaan kadar kalsium dan perbedaan karakteristik pada ibu hamil preeklampsia etnis Jawa, Madura, Cina yang mempengaruhi kejadian preeklampsia.

Bahan dan Metode: Penelitian cross-sectional dengan sampel pasien preeklampsia di RSUD Dr. Soetomo, RSUD. M. Soewandhi, dan RS Universitas Airlangga Surabaya. Pada sampel kadar kalsium total serum darah diukur sebelum pemberian $\mathrm{MgSO}$ dengan metode dimensi kimia klinis secara in vitro di Laboratorium Patologi Klinik RSUD Dr. Soetomo. Teknik pengambilan sampel meng-gunakan consecutive sampling. Sampel sebesar 53 ibu preeklamp-sia yang terdiri dari etnis Jawa, Madura, dan Cina. Hasil: Didapatkan 53 pasien preeklampsia dengan perbedaan ratarata pada usia pada etnis Jawa 31,21 $\pm 5,76$, etnis Madura 34,20 $\pm 5,58$, dan etnis Cina 28,20 $\pm 2,16$. Etnis Jawa menunjukkan BMI $31,19 \pm 5,99$, etnis Madura 27,66 $\pm 4,74$, dan etnis Cina 26,24 $\pm 2,13$. Perbedaan kadar kalsium total yang signifikan dari ketiga etnis adalah: Madura 7,7 mg/dL, Jawa $8,3 \mathrm{mg} / \mathrm{dL}$, dan Cina 9,0 mg/dL $(\mathrm{p}=0,000)$.

Simpulan: Kadar kalsium total darah pada ibu preeklampsia paling rendah terdapat pada etnis Madura. Semakin rendah kadar kalsium, semakin buruk tingkat keparahan preeklampsia. (MOG 2017;25:86-91)
\end{abstract}

Kata kunci: Preeklampsia; kadar kalsium; etnis

\begin{abstract}
Objectives: To analyse difference of calcium levels and characteristics between Javanese, Madurese, and Chinese pre-eclamptic women that affects preeclampsia incidence.

Materials and Methods: This was a cross-sectional study with preeclamptic patients in Dr. Soetomo Hospital, Dr. M. Soewandhie Hospital, and Universitas Airlangga Hospital as sample. Sample was taken by measuring total calcium level in blood serum before receiving $\mathrm{MgSO} 4$ using in vitro clinical chemical dimension method in the Laboratory of Clinical Pathology in Dr. Soetomo Hospital. Sample was taken using consecutive sampling. Sample size 53 preeclamptic women as participants of this study, divided into three groups of Javanese, Madurese, and Chinese.

Results: There were 53 preeclampsia patients, with mean ages:

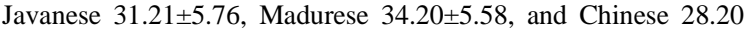
\pm 2.16 . Mean BMI: Javanese 31.19 \pm 5.99 , Madurese 27.66 \pm 4.74 , and Chinese 26.24 \pm 2.13 . We found significant difference in total calcium levels. In Madurese it was $7.7 \mathrm{mg} / \mathrm{dL}$, Javanese was 8.3 $\mathrm{mg} / \mathrm{dL}$, and Chinese was $9.0 \mathrm{mg} / \mathrm{dL}(\mathrm{p}=.000)$.

Conclusion: The highest severity of preeclampsia was in the Madurese with low calcium levels. The lowest the calcium level, the worst the severity of the preeclampsia. (MOG 2017;25:86-91)
\end{abstract}

Keywords: Preeclampsia; calcium level; ethnicity

Correspondence: Nuzulul Azizah Ramdan Wulandari, Jl. Imam Bonjol Gg. Mawar, Malang 65144, Indonesia. Phone: +6285646200833. E-mail: narwulandari@gmail.com

\section{INTRODUCTION}

Preeclampsia remains a serious complication in pregnancy and its pathophysiology is still not known with certainty. Many factors lead to increased incidence of preeclampsia in pregnant women. Preeclampsia/ eclampsia is also affected by parity, genetics and environmental factors. Racial and genetic factors are important elements because they support the incidence of underlying chronic hypertension. In Dr. Soetomo Hospital, Surabaya, in 2014 , found that $81.5 \%$ of Javanese and $18.46 \%$ of Madurese women suffered from preeclampsia. ${ }^{1}$ At Parkland Hospital, among 5,622 nulliparas who gave birth in $1986,18 \%$ of white women, $20 \%$ of Hispanic women, and $22 \%$ of black women developed hypertension that aggravated pregnancy. The incidence of hypertension in pregnancy for multiparas was $6.2 \%$ in whites, $6.6 \%$ in Hispanics, and $8.5 \%$ in blacks, which suggests that black women are more commonly affected by underlying hypertensive diseases. ${ }^{2}$ Racial factors support the occurrence of hypertension based on the consumption of foods that are the source of calcium, such as anchovies, shrimp, green vegetables, and various dairy products such as cheese. ${ }^{3}$ Pregnant women who later have severe preeclampsia have a low calcium intake compared with normotensive women. ${ }^{4,5}$

It is hypothesized that a low calcium intake causes elevated high blood pressure by stimulating the release of parathyroid hormone and/or renin leading to an increase in intracellular calcium concentration in vascular smooth muscle cells and resulting in increased resistant peripheral vasoconstriction. Finally, there is an increase in blood pressure. When calcium in blood is below critical point, the muscle can not relax after contraction. As a result, the body exhibits symptoms of seizures. ${ }^{6}$

From our observations so far, very few Chinese have experienced preeclampsia compared with Javanese and Madurese. One of the factors we suspected to cause this difference is the different intakes and diets between ethnicities that might affect calcium levels. Until now there has been no research data on calcium levels of preeclamptic mothers in ethnic Javanese, Madurese, and 
Chinese. This study aims to determine differences in calcium levels in preeclamptic pregnant women from ethnic Javanese, Madurese, and Chinese.

\section{MATERIALS AND METHODS}

Sample in this study was preeclamptic pregnant mothers who visited and admitted at the Department of Obstetrics and Gynecology in Dr. Soetomo, Dr. M. Soewandhie, and Universitas Airlangga Hospital, Surabaya, from April to June 2017. The preeclampsia groups were taken using consecutive sampling. Preeclampsia criteria used were from ISSHP 2014 with gestational age >20 weeks, accompanied by one or more organ disorders, and blood pressure $>140 / 90 \mathrm{mmHg}$. The exclusion criteria were patients suffering from osteo-porosis and superimposed hypertension.

Sample consisted of 53 preeclamptic mothers comprising 28 ethnic Javanese, 20 ethnic Madurese and 5 ethnic Chinese. Sampling was done by measuring total serum calcium levels of $5 \mathrm{cc}$ in the patients at the time of admission and before the administration of $\mathrm{MgSO} 4$ using clinical chemistry tube. The examination was done at the laboratory at Diagnostic Center Building, Dr. Soetomo Hospital, Surabaya, with the method of in vitro clinical chemical dimension. In this study, differences in calcium levels among the ethnicities were tested using Kruskal-Wallis and Mann-Whitney U statistical tests with alpha value of 0.05 . The KruskalWallis analysis technique was used to test the comparative hypothesis of independent $\mathrm{k}$ samples when the data were ordinal from more than two different populations.

\section{RESULTS AND DISCUSSION}

The study involved 53 samples of preeclamptic mothers divided into 3 groups: 28 ethnic Javanese, 20 ethnic Madurese and 5 ethnic Chinese. Table 1 shows that from some pregnant women's characteristics of preeclampsia, significant differences were found in maternal age of ethnic Javanese, Madurese, and Chinese. The average nominal difference in Body Mass Index was obtained from each ethnic group, but does not show any significant difference. Most (53.6\%) Javanese pregnant women suffered from preeclampsia, while those with severe preeclampsia were $46.4 \%$. In contrast, in Madurese pregnant women, from 20 samples, $55 \%$ suffered severe preeclampsia, $40 \%$ had preeclampsia and 5\% had eclampsia. In those pregnant women, most of ethnic Chinese suffered from preeclampsia with a percentage of $60 \%$ and $40 \%$ suffering from severe preeclampsia.

The results showed differences in preeclamptic pregnant women's characteristics of Javanese, Madurese and Chinese ethnicities at the age of the diagnosis and mean Body Mass Index in each ethnic group. Of the total of 53 preeclamptic pregnant women, the ages of ethnic Javanese mothers were 21-44 years, whereas age of $>35$ years had a risk factor for the occurrence of preeclampsia. Madurese were aged between 22 and 43, while ethnic Chinese were found at 25-30 years of age. A study in Iran found that the incidence rate of preeclampsia was also the highest in age group $>35$ years, as much as $76.4 \%$ than other age groups. ${ }^{7}$ In pregnant women less than 20 years of age and 35 years of age or older the reproductive organs are not ready for pregnancy so that those ages are more at risk for preeclampsia. According to Rochjati, susceptibility to preeclampsia is due to changes in the uterine tissue and birth canal, ${ }^{8}$ in addition to an increase in blood pressure with age. Therefore, women 35 years of age or older are more likely to have an increased risk of preeclampsia. ${ }^{9}$

Among Madurese, the average mothers suffered from preeclampsia at the age of $22-43$ years. This finding is supported by Khairul's research that in Madurese women, especially those in rural areas, there is a tradition to marry at a very young age, even according to the law is still in the category of children.

Table 1. Characteristic differences based on ethnicity

\begin{tabular}{lcccc}
\hline \multicolumn{1}{c}{ Characteristics } & $\begin{array}{c}\text { Javanese }(\mathrm{n}=28) \\
\text { Mean } \pm \text { SD }\end{array}$ & $\begin{array}{c}\text { Madurese }(\mathrm{n}=20) \\
\text { Mean } \pm \text { SD }\end{array}$ & $\begin{array}{c}\text { Chinese }(\mathrm{n}=5) \\
\text { Mean } \pm \text { SD }\end{array}$ & $\mathrm{P}$ \\
\hline Age (years) & $31.21 \pm 5.76$ & $34.20 \pm 5.58$ & $28.20^{*} \pm 2.16$ & 0.018 \\
Parity (pregnancy history) & $2.07 \pm 0.90$ & $2.95 \pm 1.73$ & $1.40 \pm 0.54$ & 0.399 \\
Gestational age (weeks) & $34.57 \pm 4.36$ & $32.70 \pm 5.19$ & $30.60 \pm 5.68$ & 0.054 \\
BMI & $31.19 \pm 5.99$ & $27.66 \pm 4.74$ & $26.24 \pm 2.13$ & 0.117 \\
Early onset & $11(47.8 \%)$ & $9(39.1 \%)$ & $3(13.0 \%)$ & \\
Late onset & $17(56.7 \%)$ & $11(36.7 \%)$ & $2(6.7 \%)$ & \\
\hline
\end{tabular}


This habit is basically shown by an engagement bond for a girl who has entered the age of menstruation or after the girl has had her first menstruation, or menarche, thus causing a long fertile period. Due to this longer fertile periods, they have the opportunity to have children in larger numbers despite the condition of mother's age $>35$ years, especially if they do not follow family planning program. The increase in welfare over the past three decades is evident with the menarche age of $0.145 /$ decade. $^{10}$ Research conducted by Hendrawati found the number of menarche in Pamekasan was 12.62. Of course, the age of menarche has a variety of variations, either based on the level of economy, environment, nutritional level of consumption, or the level of education of the mothers.

In BMI characteristics, Javanese ethnic groups tended to be higher than those of Madurese and Chinese, as seen from the average Javanese BMI rate of 31.19 (obese grade I), Madurese 27.66 (overweight), and ethnic Chinese 26.24 (overweight ). In Shanti's 2014 study, out of 91 samples, it was found that regarding BMI in Madurese, $6.6 \%$ showed less nutrition, $28.6 \%$ normal, $30.8 \%$ overweight, and $31.4 \%$ obesity. In Pooyane's study, of 92 pregnant women with preeclampsia, 74 had an average body mass index of $30 \pm 6.2 \mathrm{~kg} .{ }^{11}$ The risk of preeclampsia doubled every $5-7 \mathrm{~kg} / \mathrm{m} 2$ increase in body mass index before pregnancy. This relationship persists in studies that have excluded women with chronic hypertension, diabetes mellitus or multiple pregnancies. ${ }^{12}$ A study at Dr RD Kandou Hospital, Manado, within one year showed that from 39 samples of mothers with a diagnosis of preeclampsia, $35.9 \%$ were obese grade I and obese grade II. ${ }^{13}$

Table 2. Differences in calcium levels in preeclamptic pregnant women of Javanese, Madurese and Chinese ethnic

\begin{tabular}{lcc}
\hline \multirow{2}{*}{ Ethnicities } & \multicolumn{2}{c}{ Calcium level } \\
\cline { 2 - 3 } & Mean \pm SD & $\mathrm{p}$ \\
\hline Javanese & $8.3 \pm 0.36 \mathrm{mg} / \mathrm{dL}$ & \\
Madurese & $7.7 \pm 0.40 \mathrm{mg} / \mathrm{dL}$ & 0.000 \\
Chinese & $9 \pm 0.29 \mathrm{mg} / \mathrm{dL}$ & \\
\hline
\end{tabular}

From this study we found differences in calcium levels among the three ethnic groups of Javanese, Madurese and Chinese. Of 53 samples of preeclamptic mothers, the $p$ value was $0.000(<0.05)$, which means significant difference in the calcium level of the preeclamptic mothers. In previous studies, hypocalcemia is one of the factors that play a role in the pathogenesis of preeclampsia. ${ }^{14}$
During pregnancy total serum calcium levels fall as a result of decreased albumin levels, but the ionized calcium content is unchanged. The mean total blood calcium content in pregnant women will decrease as the gestational age increases. ${ }^{15,16}$ One study suggests that the incidence of preeclampsia is inversely related to calcium intake, meaning that the more calcium intake the lower the incidence of preeclampsia. ${ }^{14}$ Low calcium consumption is possible due to some taboos for pregnant women in consuming food.

The association between calcium intake and hypertensive disorders in pregnancy was first described in $1980 .^{17}$ This is based on the observation that the Mayan Indians in Guatemala, who traditionally soak their corn in lime before cooking, have high calcium intake and low incidence of preeclampsia and eclampsia. The very low prevalence of preeclampsia has been reported from Ethiopia where food is high in calcium. ${ }^{18}$ These observations are supported by other epidemiological and clinical studies, ${ }^{17,19}$ which suggest the hypothesis that increased calcium intake during pregnancy can reduce the incidence of high blood pressure. High blood pressure and preeclampsia are found in women with low calcium intake. Associations have been found between preeclampsia and hypocalciuria, ${ }^{20}$ decreased urinary calcium and creatinine, ${ }^{21}$ hypocalcaemia,${ }^{22}$ lower plasma and higher calcium membranes, ${ }^{23}$ lower intake of dietary milk, ${ }^{24}$ and between eclampsia and hypocalcaemia. $^{25}$

There is a difference in the levels of calcium among the three ethnicities we examined. This may be due to the difference in diet/intake that is strongly influenced by each culture. In Madurese, there are some myths that prohibit pregnant women from consuming sea fish, octopus, and squid. The low rainfall makes land in Madura less fertile and less economically beneficial. This is what makes many Madurese to switch jobs to fishing or migrating. ${ }^{26}$ Because most of them are fishermen, most Madurese pregnant women consume lots of salt (Na). Imantino's study (2013) found that approximately $90 \%$ of patients with hypertension are patients who consume food sources containing sodium more than needed. Calcium has a netriuretic effect, and is influential in lowering blood pressure in patients with $\mathrm{NaCl}$-sensitive hypertension. When $\mathrm{NaCl}$ intake is excessive, an increase in urinary calcium excretion, parathyroid hormone levels, and concentrations of 1.25dihydroxivitamin $\mathrm{D}$. The thyroid hormone causes vasoconstriction by affecting neural activity and/or vasoactive hormone. $^{27}$ 
Table 3. The average distribution of calcium levels on preeclamptic severity among ethnic Javanese, Madurese, Chinese

\begin{tabular}{llcc}
\hline Ethnicities & Types of preeclampsia & N & $\begin{array}{c}\text { Calcium level } \\
\text { Mean } \pm \text { SD }\end{array}$ \\
\hline Javanese & Preeclampsia & 15 & $8.62 \pm 0.086$ \\
& Severe Preeclampsia & 13 & $8.00 \pm 0.26$ \\
Madurese & Preeclampsia & 11 & $7.89 \pm 0.36$ \\
& Severe Preeclampsia & 8 & $7.53 \pm 0.31$ \\
Chinese & Eclampsia & 1 & $7.00 \pm 0.00$ \\
& Preeclampsia & 3 & $9.10 \pm 0.36$ \\
& Severe Preeclampsia & 2 & $8.85 \pm 0.07$ \\
\hline
\end{tabular}

In Javanese ethnic culture, during pregnancy to birth a Javanese woman must obey the various taboos, among which are not allowed to eat goat meat, not allowed to eat catfish, prohibited from eating octopus, squid, crab, shrimp and stingray. ${ }^{28}$ These abstinence ultimately lead pregnant women to malnutrition, such as anemia and chronic energy deficiency. The dietary abstinence from animal classes (shrimp, squid and stingrays) included foods containing iron class of hem, ie iron derived from haemoglobin and myoglobin. Iron in animal foods has higher absorption, ie 20-30\%, while from vegetable sources only $1-6 \%{ }^{29}$

In Susianita's study, the average ethnic Chinese frequently consume high-calcium foods, among which $33.3 \%$ often consume tempeh, $13.7 \%$ frequently consume eggs, $66.7 \%$ occasionally consume meat, $15.7 \%$ sometimes consume squid, $11.8 \%$ occasionally consume shrimp, $25.5 \%$ often consume kale, and $56.9 \%$ occasionally consume spinach. ${ }^{30}$ The results of a study published in the journal World Menu Report write that China is the top country whose population thinks about the safety of food, whether food is processed hygienically, and the nutritional content in the diet is also considered.

Table 3 shows that the lower the total calcium level, the more severe the clinical condition of preeclampsia. Spearman Correlation test produced sig. 0.000, which means there was a correlation between the severity of preeclampsia with calcium levels. The more severe the clinical preeclampsia, the more decreased total calcium levels in the blood. In this study we found that total calcium levels in preeclamptic mothers had an effect on the clinical severity of preeclampsia. The lower the mother's calcium level, the higher the severity of preeclampsia. This can be seen from the occurrence of eclampsia in mothers who have lower levels of calcium than severe preeclampsia and preeclampsia. Pregnant women who will experience severe preeclampsia have a lower calcium intake than women with normal blood pressure. $^{31,5}$ Several studies have shown that plasma
$\mathrm{Ca} 2+$ levels fall slightly in normal pregnancy and decline sharply in preeclampsia. ${ }^{32}$ Similar study was conducted at Dr. Soetomo Hospital in 1994 on differences in intracellular calcium levels, total calcium levels and parathyroid hormone levels in primigravida preeclampsia/eclampsia and normal third trimester pregnancy. The study found that the difference in total calcium levels in preeclampsia-eclampsia $(8.82 \pm 1.7 \mathrm{mg}$ $\mathrm{dL})$ tended to be lower than in the normotensive pregnancy group $(9.44 \pm 1.33 \mathrm{mg} / \mathrm{dL})$.

Table 4. Differences in calcium levels in pregnant women with preeclampsia between two different ethnic groups.

\begin{tabular}{lc}
\hline \multicolumn{1}{c}{ Groups } & $\mathrm{P}$ \\
\hline Javanese and Madurese & 0,001 \\
Javanese and Chinese & 0,050 \\
Madurese and Chinese & 0,003 \\
\hline
\end{tabular}

Table 4 shows the results of statistical tests with Mann Whitney $U$ to see the difference in calcium levels between each of two ethnicities. In Javanese and Madura ethnic groups, there was significant difference $(p=$ $0.001)$. Significant results were also found in Madurese and Chinese $(\mathrm{p}=0.003)$. In Javanese and Chinese ethnic group, the $\mathrm{p}$ was 0.050 , showing significant result.

\section{CONCLUSIONS}

There was difference in calcium levels in preeclamptic mothers of ethnic Javanese, Madurese and Chinese. Madurese were found to have the lowest calcium content of $7.7 \mathrm{mg} / \mathrm{dL}$, followed by Javanese with an average of $8.3 \mathrm{mg} / \mathrm{dL}$ and $9.0 \mathrm{mg} / \mathrm{dL}$ Chinese. There was a correlation between total calcium levels and the severity of preeclampsia. 


\section{REFERENCES}

1. Mawwadah KA. Karakteristik dan cara persalinan ibu dengan preeklampsia berdasarkan faktor etnis di kamar bersalin RSUD. Dr. Soetomo Surabaya tahun 2014. Karya Tulis Ilmiah. 2013.

2. Cunningham GF, Gant FN, Leveno JK, et al. Hipertensive disorder in pregnancy. Williams Obstetrics. 21st edn; 2001. p. 587-809.

3. Widyakarya Nasional Pangan dan Gizi tahun 2014.

4. Rakhsanda A, Fauzia P, Syeda R, Saima S. Serum calcium level and pregnancy induced hypertension. Dow Medical Sciences \& College; 2012. p. 63-5.

5. Zuzana A, Sifa O, Razif A. Vascular and cellular calcium in normal and hypertensive pregnancy. Curr Clin Pharmacol. 2009;1:23-2.

6. Jaya Kusuma AAN. Manajemen risiko pada preeklamsia. In: Pendidikan kedokteran berkelanjutan obstetri dan ginekologi. Denpasar: FK Unud /RSUP Sanglah; 2004. p. 49-66.

7. Yazdani M, Amirshani E, Shakeri A et al. Prenatal and maternal outcomes in advanced maternal age, a comparative study. Women's Health Bull. 2015: 2(2); e23092.

8. Rochjati P. Skrining antenatal pada ibu hamil. Pusat Safe Motherhood. Surabaya: Lab/SMF Obgyn RSUD. Dr. Soetomo/Fakultas Kedokteran Universitas Airlangga Surabaya; 2003.

9. Potter PA and Perry AG. Buku ajar fundamental keperawatan: Konsep, proses dan praktik. 4th edition. (Komalasari R et al. transl.). Jakarta: EGC; 2005.

10. Noer KU. (2008). Angka kematian bayi dan persoalan kesehatan ibu hamil dalam budaya Madura. Undergraduate Thesis. Postgraduate Pro-gram of Social Sciences. Universitas Airlangga.

11. Pooyane T. Impact of severe preeclampsia on maternal and fetal ourcomes in preterm deliveries. [internet] [cited 2017 Jun 4]. Available from http: //wiredspace.wits.as.za/jspui/bitstream/10539/1842 4/1/Final\%20Submission.pdf.

12. O 'Brien TE, Raj JG, Chan WS. Maternal body mass index and the risk of preeclampsia: a systematic overview'. Epidemiology 2003; 14: 368-374.

13. Dumais CEG, Lengkong RA, Mewengkang ME. Hubungan obesitas pada kehamilan dengan preeklampsia. Jurnal e-Clinic (eCI), 2016;4(1).

14. Patterson BW. Calcium deficiency as the prime cause of hypertension in pregnancy: a hypothesis. Asia-Oceania J Obstet Gynecol. 1984;10:485- 98

15. Christhoper SK. Calcium metabolism during pregnancy and lactation. Faculty of Medicine-Endocrinology. University of Newfoundland, 2012: Chapter 3 .
16. Power ML, Heaney RP, Kalkwarf HJ. The role of calcium in health and disease. Am J Obstet Gynecol. 1999;181:1500-9.

17. Belizan JM, Villar J, Repke J. The relationship between calcium intake pregnancy induced hypertension: up to date evidence. Am J Obstet Gynecol. 1998;158:898-902.

18. Hamlin RHJ. Prevention of pre-eclampsia. Lancet. 1962;1:864-5.

19. Villar J, Abdel A, Meriadi M, et al. World health organization randomized trial of calcium supplementation among low calcium intake pregnant women. Am J Obstet Gynecol. 2006;194: 639-49.

20. Segovia BL, Vega IT, Villarreal EC, Licona NA. Hypocalciuria during pregnancy as a risk factor of preeclampsia'. Ginecology Obstetricia de Mexico. 2004;72:570-4

21. Kazerooni T, Hamze-Nejadi S, Kazerooni $T$, Hamze-Nejadi S. Calcium to creatinine ratio in a spot sample of urine for early prediction of preeclampsia'. International Journal of Gynecology \& Obstetrics. 2003;80:279-83.

22. Kumru S, Aydin S, Simsek M, et al. Comparison of serum copper, zinc, calcium, and magnesium levels in preeclamptic and healthy pregnant women. Biological Trace Element Research. 2003;94:10512

23. Kisters $\mathrm{K}$, Barenbrock $\mathrm{M}$, Louwen $\mathrm{F}$, et al. Membrane, intracellular, and plasma magnesium and calcium concentrations in preeclampsia. American Journal of Hypertension. 2000;13:765-9.

24. Duvekot EJ, de Groot CJ, Bloemenkamp KW, Oei SG. Pregnant women with a low milk intake have an increased risk of developing preeclampsia'. European Journal of Obstetrics \& Gynecology and Reproductive Biology. 2002;105:11-4.

25. Isezuo $\mathrm{S}$ and Ekele BA. Eclampsia and abnormal QTc. West African Journal of Medicine. 2004;23: 123-7.

26. De Jonge H. Madura dalam empat zaman: pedagang, perkembangan ekonomi dan islam. Jakarta: Gramedia; 1989.

27. Alfiana N, Bintanah S, Kusuma H. Hubungan asupan kalsium dan natrium terhadap tekanan darah sistolik pada penderita hipertensi rawat inap di RS. Tugerojo Semarang. Jurnal Gizi Universitas Muhammadiyah Semarang. 3;1.

28. Handayani S. Aspek sosial budaya pada kehamilan, persalinan dan nifas di Indonesia. Thesis. 2010.

29. Nurhaeni A. Kehamilan dan kelahiran sehat. Yogyakarta: Dian Loka; 2008.

30. Pangarubuan S, Aritonang EY, Siregar MA. Pola makan dan status gizi keluarga etnis Tionghoa Kelurahan Asam Kumbang Kecamatan Medan Selayang Tahun 2014. Undergraduate Thesis, Universitas Sumatra Utara. 
Wulandari et al. : Difference of calcium levels in Javanese, Madurese, and Chinese preeclamptic women

31. Rakhsanda A, Fauzia P, Syeda R, Saima S. Serum calcium level and pregnancy induced hypertension. Dow Medical Sciences \& College. 2012;18:63-65.
32. Sukonppong P. Serum calcium and serum magnesium in normal and preeclampsia pregnancy. Arch Gynecol Obst. 2005;214(1):12-6. 